真空工学とその応用のためのガス放出測定*

稲 吉 さかえ*1

\title{
Outgassing Measurement for Vacuum Engineering
}

Sakae INAYOSHI*1

*11ULVAC, Inc., 2500 Hagisono, Chigasaki-shi, Kanagawa 253-8543, Japan

(Received February 21, 2014, Accepted December 18, 2014)

\begin{abstract}
In this article, two common methods to evaluate the outgassing properties of vacuum system materials, thermal desorption spectroscopy (TDS) and the method of switching between two pumping paths (SPP), are discussed. TDS can evaluate the outgassing properties of small samples, while SPP method can measure low outgassing rate, such as the case after baking. Ion gauges and/or quadrupole mass spectrometers (QMS) consist of the TDS and SPP setups. In these cases, QMS are typically calibrated using a standard conductance element (SCE). The calibration using the SCE enables the direct conversion of the QMS ion current into the gas flow rate.
\end{abstract}

\section{1. はじめに}

真空装置では, 真空ポンプを用いて真空容器内の空間に漂 う気体分子を排出して真空の状態をつくっている. 排出しな ければならない気体は, 容器内の大気だけではない。大気の 他にも, 真空容器内壁や真空容器内の部品の表面に付着して いた分子や，それら材料の内部に吸収されていた分子が徐々 に空間に放出されるため，それらの気体も排出しなければな らない。このように真空容器の真空の状態は, 中に入れる材 料の気体放出特性に影響されるので, 材料からの気体放出は 極力少ないことが望なしい，材料やその表面処理を選定する ために, 真空中で用いる材料の気体放出特性データが長年に わたり収集されてきた. 真空材料の構造材料として使われる ステンレス鋼やアルミニウム合金の表面処理, 表面粗さを変 えたときの気体放出特性が比較され, まとめられてい る1-4). 核融合炉用材料 5,6$)$, 低ガス放出材料, 表面処理とし て, TiN 薄膜7,8) やアルミニウム陽極酸化処理 ${ }^{9)}, \mathrm{BN}$ 薄 膜10), チタン及びチタン合金やその表面処理11,12), $\mathrm{Cu}$ 合金 材料13)など, また, 加速器関係で, 高 Mn ステンレス 鋼 ${ }^{14)}$, アルミナ複合材 ${ }^{15)}$, 各種電線 ${ }^{16)}$, 合成樹脂 ${ }^{17)}$, 磁石 材料18)等の真空材料の気体放出測定が報告されている.

気体放出の要因には, 熱, 光, 荷電粒子, 摩擦等の刺激, 反応性気体と材料の接触等多くのものが挙げられ，それぞれ の気体放出特性を測定するための装置が製作されている. 本 稿では，それらの中でも最も多くの測定データが存在してい る熱脱離による気体放出測定方法に関して, 確からしい測定 をするための工夫を交えて我々が評価用に製作した装置につ いて述べる.

\section{2. 気体放出特性測定手法}

真空装置に使う真空材料からの気体放出特性を測定する代 表的な手法は 2 つある.

一つは試料の温度を上昇させ, 温度上昇の過程で放出され

$*$ 平成 25 年 7 月 3 日 日本真空学会2013年 7 月研究例会で発表

*1 侏アルバック（干253-8543 神奈川県茅ケ崎市萩園2500）
る気体の量とガス種を測定するもので昇温脱離（TDS: Thermal Desorption Spectroscopy) 法と呼ばれる. TDS 法 はRedhead ${ }^{19)}$, Carter ${ }^{20)} に よ り$ 確立された手法である. 単結 晶表面上の特定の元素, 分子について, 脱離の活性化エネル ギーを正確に求めたり, 吸着の次数を求めるなど, 吸着と脱 離現象の詳細な解析に用いられている. 気体放出速度, 気体 放出量, 放出される気体の種類がわかることから, 実用表面 である真空材料の評価にも応用されている.なお TDS 法に よる微小片を試料にしたガス放出評価方法については文 献21) に詳細に解説されている. TDS 法に用いる試料は数 10 $\mathrm{cm}^{2}$ で比較的小さく, 数時間から 1 日程度の短時間で評価が 可能である. 複数の比較したい試料を同一条件で測定し, 相 対的に評価する.

もう一つは, 室温での気体放出速度, 気体種類を評価する 手法である. 大気圧から排気したときの気体放出速度の経時 変化や, ベーキング後の室温での気体放出速度を得るために 用いられる. 例えば, スループット法 (差圧流量法) ${ }^{22)}$, ビ ルドアップ法22), コンダクタンス変調法 ${ }^{23)}$, 流路切り替え (SPP: Switching between Two Pumping Paths) 法24)などが 知られている。これらのうち, コンダクタンス変調法と SPP 法は, ポンプからの気体の逆流や, 真空計からの気体 放出など, 試料から放出される気体放出測定の誤差になるも のを除去する方法として考案された. 超高真空や極高真空領 域で使われる材料のベーキング後の室温における到達圧力付 近での気体放出速度測定をより正確に行うことができる.

室温での気体放出速度測定では, 試料とバックグランドの ガス放出速度の差が小さくなるため, 表面積の大きい試料が 必要となる．測定時間は半月程度の長時間を要する。

上記 2 つ手法は, いずれも試料から放出された気体分 子が測定装置の真空容器内壁に再入射して相互作用し, 再脱 離するということを繰り返した後, 検出器で検出される. 試 料から放出された気体分子を直接測定するには, 分子線 法25)を用いる必要がある。

放出気体の成分比を正しく把握するためには四重極質量分 析計や全圧計の校正が重要であるため，校正方法についても 詳しく述べた. 


\section{3. 昇温脱離法 (TDS)}

\subsection{TDS 測定装置}

Fig. 1 に TDS 装置の概略図を示す。この装置は石英ガラ ス製チューブを含む測定室を大気解放し，K 熱電対を点溶 接した試料を石英ガラス直上の熱電対導入ポートからつりさ げて測定装置内に導入する。排気経路 1 で一定時間排気 後, 排気経路 2 に切り替えて一定時間排気する. その後試 料を一定昇温速度で加熱し TDS 測定を行う. 赤外線ゴール ドイメージ炉により，石英ガラスを通して真空外部から試料 のみを加熱する. 気体放出流量はオリフィス上流側及び下流 側に取り付けた B-A（Bayard-Alpert）真空計を用いてス ループット法で求める. ガス種はオリフィス上流側の四重極 質量分析計（QMS）を用いて検出する．この装置において， 検出器である B-A 真空計, 四重極質量分析計は, 試料交換 時にも常に真空中にあり，大気に懪されることはない。測定 をしていないときには常に超高真空状態に置かれている.し かし熱電対と試料室は試料交換の際に大気压に曝される。そ のため, 試料室, 熱電対からの気体放出が比較的大きな值の バックグランドとなる，バックグランドを低減するために, 測定室が大気にさらされない様にマニピュレータで試料を搬 送するTDS 装置もある ${ }^{26)}$ 。われわれが製作した試料搬送式 の装置と Fig. 1 の装置を比較すると, 試料搬送式の方が一 桁程度測定下限は低い。しかし，Fig. 1 の装置では試料形状 がある程度自由になるのに対し，試料搬送式の装置では測定 可能な試料形状が平板に限られる.

Fig. 1 の装置では, 検出器である B-A 真空計, 及び四重 極質量分析計は，ポンプまでの間の配管に流れと垂直な方向 に取り付けた。TDS 測定の主な検出器は，一般的には四重 極質量分析計であるが，真空材料の評価の場合には，気体放 出速度を評価の尺度にしたいということと感度の経時変化が 少ないという理由から, 窒素圧力表示の B-A 真空計と窒素 に対するコンダクタンスとを用いて，気体放出速度を算出で きる装置構成とした。

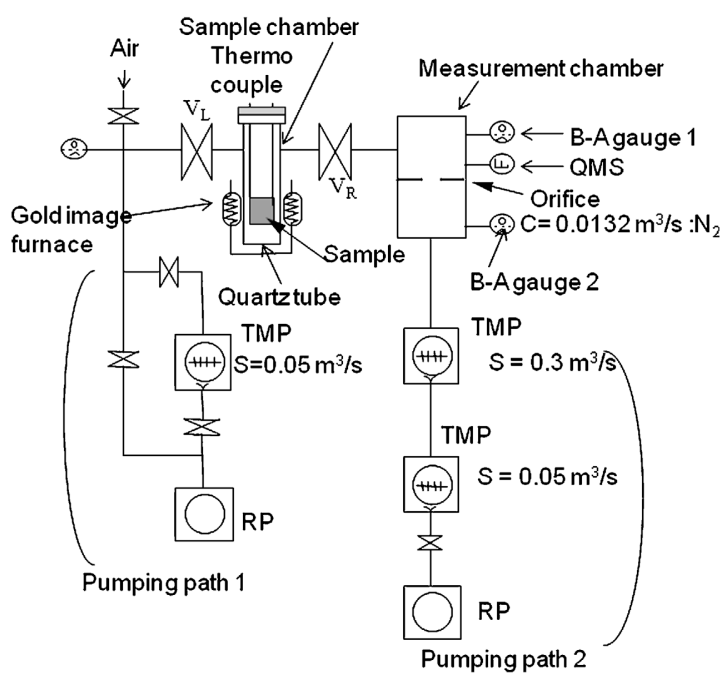

Fig. 1 Schematic diagram of thermal desorption spectrometer.
Chan 等は定量的な誤差の解析を行い, 昇温脱離測定の 際, 圧力が脱離速度に比例する条件として, 昇温速度 $\beta$ と 測定系の排気の時定数 $\tau$ の関係式(1)を導いた ${ }^{27)}$.

$$
\frac{1}{\beta \tau} \geq 0.5
$$

本装置の場合, 容積 $\mathrm{V}=5.5 \times 10^{-3} \mathrm{~m}^{3}$, オリフィスコンダク タンス $\mathrm{C}=1.32 \times 10^{-2} \mathrm{~m}^{3} \mathrm{~s}^{-1}$ なので，時定数 $\tau=\mathrm{V} / \mathrm{C}=$ $0.417 \mathrm{~s}$ であり，したがって $\beta \leqq 4.8 \mathrm{~K} / \mathrm{s}$ となる．通常本装置 で測定を行うときには，昇温速度 $\beta$ は $0.1 \sim 0.2 \mathrm{~K} / \mathrm{s}$ であ り，(1)の条件を満たしている.

いずれの検出器も試料が直接見える位置には設置されてい ない，検出器が試料を直視していない装置構成では，金属材 料を加熱した場合，その金属が蒸発する温度に十分達してい て実際に蒸発していても，その金属を検出することはできな い.しかし，検出器に蒸発した金属が直接入らないことは， 検出器の污染防止になり，安定な測定ができるという利点と なる。

気体放出特性を測定する際には, 測定前の試料及び, 装置 の状態が測定結果に影響を及ぼす。例えば試料がポリマーの 袋に直接触れて保管されていた場合，同一の表面処理を行っ た試料を複数個測定したとき，測定值のばらつきが大きくな るという影響がみられた。 また，測定のバックグランドの変 動を極力小さくするために，測定前の試料が保管される場所 や，試料を装置に入れる際に大気開放するときの湿度を一定 にすることが望ましい，検出器が試料を直視せず，装置内壁 と相互作用した後の気体の状態を検出している装置構成の場 合には特に，バックグランドの変動を抑制する方策をとるこ とで再現性の良好な結果を得ることができる。

上述した装置の製作時期はかなり古い, 最近では, 気体放 出が少ないといわれているチタンを使って昇温脱離測定装置 を製作し，真空材料の評価を行ったという報告28)もされて いる.よりガス放出速度の小さい材料で装置を製作すれば, バックグランドレベルを下げることができ，より精度の高い 測定につながると考える.

\section{2 四重極質量分析計の校正}

現在のところ四重極質量分析計の校正には決まった方法が なく, イオン電流を直接「流量」に変換できる簡便で安価で 信頼性の高い校正方法の確立が望まれている．真空計の校正 方法には標準リークを用いる方法，圧力淀みを作る方法，標 準コンダクタンスエレメント (SCE) を用いる方法などがあ る.

このうち標準リークを用いるのが，最も簡便な校正方法で ある，具体的には，決まった流量の気体を流すことができる キャピラリーを用いた標準リークを用意して，ガス種毎にイ オン電流を流量に換算する係数を求めるものである.ただし 標準リークでは，使用に伴ってキャピラリーの上流側の圧力 が低下し，リーク流量が低下する。この低下の定量的な予測 が困難という問題点がある。

真空材料からの放出気体種で最も注目される水について は，標準リークが容易に入手できない，その場合には，真空 容器に真空計の下流側から水を導入して，淀みを利用して圧 
力が一定の状態を作り, スピニングローター真空計等の絶対 圧が測定できる真空計で圧力を測定, 同時に四重極質量分析 計の $m / z=18$ のイオン電流も測定し, $m / z=18$ のイオン電流 を水の圧力に換算する係数を求める. 更に, 別途測定した排 気速度を用いて水の気体流量に变換する換算係数を求めるこ とで水の気体流量を定量化できる29). 水以外でもガスを用 意すれば同様に校正を行えるが簡便ではない。

最後に産業技術総合研究所で開発された $\mathrm{SCE}^{30)}$ を用いて 校正した例を示す．SCEは，エレメント中いずれの場所で も分子流になる条件で使用する. 分子流であれば, SCE上 流側圧力 $P_{\mathrm{f}}$ から下流側の気体流量 $Q_{\mathrm{d}}$ を(2)により計算する ことができる.

$$
\begin{aligned}
Q_{\mathrm{d}}=P_{\mathrm{f}} \times C_{\mathrm{f}} & \sqrt{\frac{28 \cdot T}{M \cdot T_{0}}} \\
& \left(\mathrm{Pam}^{3} / \mathrm{s} \text { at } T\right)
\end{aligned}
$$

ただし， $C_{\mathrm{f}}$ : あらかじめ測定した SCEの分子流コンダク タンス, $T_{0}$ : 分子流コンダクタンスを測定したときの温度, $M:$ 気体の分子量, $T:$ 温度である.

校正には, 標準コンダクタンスエレメントと校正する気 体, コンダクタンスの上流側圧力測定のための真空計, 上流 側の気体排気用のポンプ等が必要である. 用意するものと手 順を考えると, 簡便さは, キャピラリー標準リークを用いる 方法と, 圧力淀みを作る方法との中間にあたると考える. 標 準リークに比べると，上流側の圧力低下による予測できない リーク量低下がないため信頼性が高い。 また，気体さえ用意 すれば，SCEは 1 本だけであらゆる気体について校正が可 能である. 圧力淀みを作る方法に比べると, 校正に用いる気 体は少量でよく, 超高純度の高圧ガスボンベは必要ない. 更 に, イオン電流を, 圧力を介さずに, 直接流量に変換できる という利点がある。

Fig. 1 の TDS 装置では, 熱電対用の導入ポートに SCE を取り付けて QMS を校正した ${ }^{31)}$. 今回用いた SCEの分子 流コンダクタンスは, $1.237 \times 10^{-10} \mathrm{~m}^{3} \mathrm{~S}^{-1}$ (温度 : $25.9 \pm$ $1.0^{\circ} \mathrm{C}$, 圧力範囲 : $10^{2} \mathrm{~Pa} \sim 10^{4} \mathrm{~Pa}$, 相対拡張不確かさ $6.3 \%$ ) であった. 上流側圧力は, 水素では $1 \mathrm{kPa} \sim 10 \mathrm{kPa}$, 水では $0.7 \mathrm{kPa} \sim 2.2 \mathrm{kPa}$ の間で変化させた. このときの下流側流量 は, 水素で $5 \times 10^{-7} \mathrm{Pam}^{3} \mathrm{~s}^{-1} \sim 5 \times 10^{-6} \mathrm{Pam}^{3} \mathrm{~s}^{-1}$, 水で $10^{-7} \mathrm{Pam}^{3} \mathrm{~S}^{-1}$ 台前半であった.

校正後の流量感度 $S_{Q}$ (四重極質量分析計のイオン電流/気 体流量）と窒素に対する相対感度 $S_{r N 2}$ を Table 1 に示す.

Table 1 Flow rate sensitivity $\left(S_{Q}\right)$ and sensitivity relative to that of $\mathrm{N}_{2}\left(S_{r N 2}\right)$ for various gases.

\begin{tabular}{c|c|c|c}
\hline \hline $\begin{array}{c}\text { Gas } \\
\text { species }\end{array}$ & $\begin{array}{c}\text { Measured } \\
\mathrm{m} / z\end{array}$ & $\begin{array}{c}\text { Flow rate sensitivity } S_{Q} \\
\left(\mathrm{~A} /\left(\mathrm{Pam}^{3} \mathrm{~s}^{-1}\right)\right)\end{array}$ & $S_{r N 2}$ \\
\hline $\mathrm{H}_{2}$ & 2 & $1.78 \times 10^{-2}$ & 0.28 \\
\hline $\mathrm{H}_{2} \mathrm{O}$ & 18 & $3.44 \times 10^{-2}$ & 0.55 \\
\hline $\mathrm{CO}$ & 28 & $6.22 \times 10^{-2}$ & 0.99 \\
\hline $\mathrm{N}_{2}$ & 28 & $6.30 \times 10^{-2}$ & 1.00 \\
\hline $\mathrm{CO}_{2}$ & 44 & $6.45 \times 10^{-2}$ & 1.02 \\
\hline
\end{tabular}

\subsection{TDS 測定結果例}

昇温脱離測定に用いた試料は, 電解研磨したステンレス鋼 で, 試料寸法は $45 \mathrm{~mm} \times 45 \mathrm{~mm} \times 0.5 \mathrm{~mm}$ （表面積 : $4.14 \times$ $\left.10^{-3} \mathrm{~m}^{2}\right)$ である. 測定前にエタノールで超音波洗浄を行っ た. Fig. 2 は, 四重質量分析計の $m / z=2,18,28,44 の$ イ ン電流と, $m / z=2,18,28,44 の 4$ つのイオン電流の和 $\left(\Sigma\left(I_{2}\right.\right.$ $\left.\left.+I_{18}+I_{28}+I_{44}\right)\right)$ を表示した結果である. Table 1 の流量感 度を使って, Fig. 2 の $m / z=2 ， 18 ， 28 ， 44$ をれぞれ水素, 水, $\mathrm{CO}, \mathrm{CO}_{2}$ として流量に変換した昇温脱離スペクトルを Fig. 3 に示す. Fig. 3 の縦軸は, 気体放出速度 (気体流量 を表面積で割った值）になっているが, 昇温脱離測定時の流 量, 圧力は，校正時の流量・圧力範囲と同じ領域で測定でき ている.

$\left\lceil\mathrm{SUM}\right.$ QMS」は水素, 水, $\mathrm{CO}, \mathrm{CO}_{2}$ の 4 種類の気体放出 速度の積算值であり, 最も実際の気体放出速度に近いものと

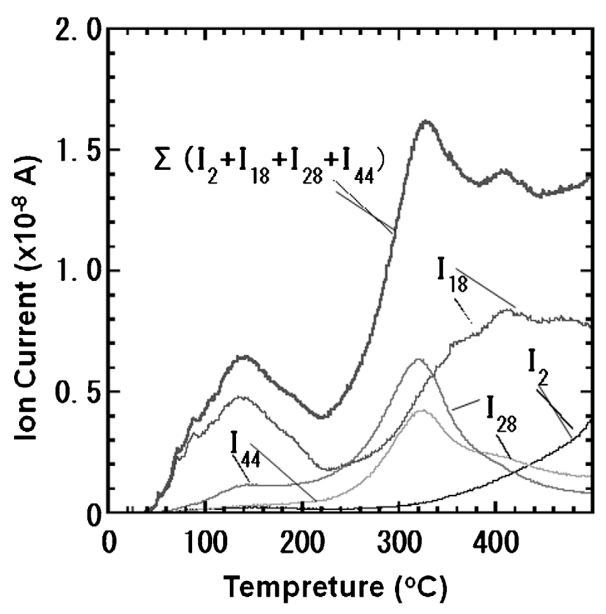

Fig. 2 Thermal desorption spectra of an electrolytically polished stainless steel (SUS304L) sample.

$I_{2}$ : ion current for $m / z=2, I_{18}$ : ion current for $m / z=18, I_{28}$ : ion current for $m / z=28, I_{44}$ : ion current for $m / z=44, \Sigma\left(I_{2}-\right.$ $\left.I_{44}\right)$ : sum of $I_{2}, I_{18}, I_{28}$, and $I_{44}$.

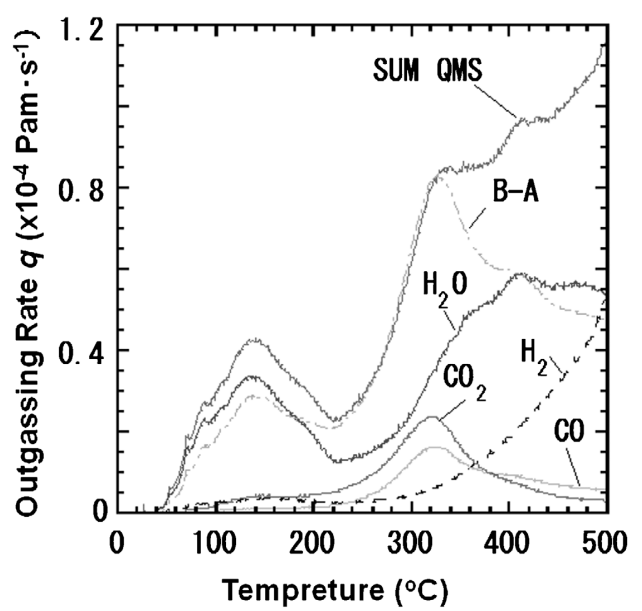

Fig. 3 Thermal desorption spectra after calibration by SCE. $\mathrm{B}-\mathrm{A}$ : outgassing rate measured by the throughput method with B-A gauges.

SUM QMS: sum of calibrated outgassing rates for $\mathrm{H}_{2}, \mathrm{H}_{2} \mathrm{O}$, $\mathrm{CO}$, and $\mathrm{CO}_{2}$. 
考える.「B-A」はオリフィス上流側および下流側の B-A 真 空計の圧力值 $P_{1}, P_{2}$ とオリフィスのコンダクタンス $C$ から 求めた.「SUM QMS」は $300^{\circ} \mathrm{C}$ 以上でも増加しているが, $\left\lceil\mathrm{B}-\mathrm{A} 」\right.$ は $300^{\circ} \mathrm{C}$ 以で減少している. また, Fig. 2 の「 $\Sigma\left(I_{2}\right.$ $\left.+I_{18}+I_{28}+I_{44}\right) 」 も 300^{\circ} \mathrm{C}$ 上上で単調には増加をして抢らず $\lceil\mathrm{SUM}$ QMS」とは異なる形状であった。

水素は, 窒素に対する流量感度が低く, また水素のコンダ クタンスは窒素に比べて大きい。このため B-A 真空計で測 定した気体放出速度もイオン電流の積算值も実際よりも小さ く評価されていたため, $300^{\circ} \mathrm{C}$ 以上での昇温脱離スペクトル の形状が合致しなかったと考える.

このように, 四重極質量分析計が校正されていないと昇温 脱離スペクトルの形状が変わってしまうことがある.

四重極質量分析計でも全圧計でも, 定量的な評価を正しく 行うには気体種類を特定しなければならない。昇温脱離測定 で高温になると, 試料表面に付着していた污れがハイドロ カーボンとして放出され，マススペクトルが複雑になるが， 気体種類特定が困難なため, これらを定量することは難しい.

\section{4. 流路切り替え（SPP）法23)}

\section{1 SPP 法測定装置}

気体放出流量を測定する手法は, 主にスループット法が用 いられている。しかし，この方法には測定する気体放出速度 が小さくなると, (1) 2 台の真空計の校正誤差や測定下限の 違いによる測定誤差が大きくなる, (2) 真空計からの気体放 出が測定值に比べ相対的に大きくなり測定誤差になる, とい う問題が生じる.これらの問題点を解決する方法として SPP 法が開発された.

SPP 測定方法の概念図を Fig. 4 に示す. 試料からの気体 放出による流量を $Q_{\mathrm{s}}$, コンダクタンス $C$ が既知のオリフィ スの上流側部分からの気体放出による流量を $Q_{U}$, オリフィ ス下流側部分からの気体放出による流量を $Q_{\mathrm{D}}$, オリフィス 上流側圧力を $P_{1}$, オリフィス下流側圧力を $P_{2}$ とし, オリフ ィス上流側の経路を通すバルブを $\mathrm{V}_{\mathrm{U}}$, 下流側の経路を通す バルブを $\mathrm{V}_{\mathrm{D}}$ とする．今， $Q_{\mathrm{S}}$ をオリフィス上流側の排気経 路 $\left(\mathrm{V}_{\mathrm{U}}\right.$ 開 $\mathrm{V}_{\mathrm{D}}$ 閉 $)$ で排気したときの圧力 $P_{1 \mathrm{u}}$ は,

$$
P_{1 \mathrm{u}}=P_{2 \mathrm{u}}+\left(Q_{\mathrm{S}}+Q_{\mathrm{U}}\right) / C
$$

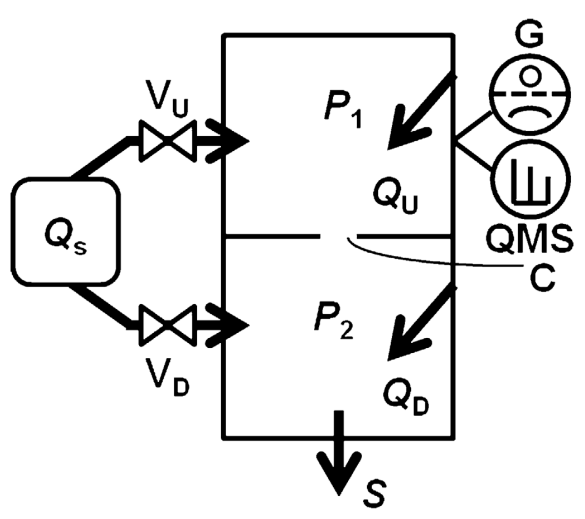

Fig. 4 Illustration diagram of explaining the concept of the SPP method.
であらわされる。ただし， $P_{2 \mathrm{u}}$ は $\mathrm{V}_{\mathrm{U}}$ 開 $\mathrm{V}_{\mathrm{D}}$ 閉のときのオリ フィス下流側圧力である.

$Q_{\mathrm{S}}$ をオリフィス下流側の排気経路 $\left(\mathrm{V}_{\mathrm{U}}\right.$ 閉 $\mathrm{V}_{\mathrm{D}}$ 開 $)$ で排気 したときの圧力 $P_{1 \mathrm{~d}}$ は,

$$
P_{1 \mathrm{~d}}=P_{2 \mathrm{~d}}+Q_{\mathrm{U}} / C
$$

ただし， $P_{2 \mathrm{~d}}$ は $\mathrm{V}_{\mathrm{U}}$ 閉 $\mathrm{V}_{\mathrm{D}}$ 開のときのオリフィス下流側圧力 である.

$P_{2}$ は全気体流量 $Q_{\mathrm{TOT}}=Q_{\mathrm{S}}+Q_{\mathrm{U}}+Q_{\mathrm{D}}$ を実効排気速度 $S$ で 割った值で $Q_{\mathrm{S}}$ の排気経路によらない.

$$
P_{2 \mathrm{u}}=P_{2 \mathrm{~d}}=P_{2}=\left(Q_{\mathrm{S}}+Q_{\mathrm{U}}+Q_{\mathrm{D}}\right) / S
$$

(3)と (4)の差をとると, 次の (6)式により試料からの単位面 積当たりの気体放出速度 $q$ を求めることができる.

$$
q=\left(P_{1 \mathrm{u}}-P_{1 \mathrm{~d}}\right) \times C / A
$$

ただし $A$ は試料表面積である. 四重極質量分析計のイオン 電流についても同様に $\mathrm{V}_{\mathrm{U}}$ 開， $\mathrm{V}_{\mathrm{D}}$ 閉のときのマススペクト ルから $\mathrm{V}_{\mathrm{U}}$ 閉， $\mathrm{V}_{\mathrm{D}}$ 開のときのマススペクトルを差し引くこ とで, 試料のみから放出された気体のマススペクトルを測定 することができる.

上記の測定概念に基づいて製作した測定装置概略図を Fig. 5 に示す. 本測定装置では, 大気暴露後の気体放出速 度の変化など, 気体放出速度が大きい測定の場合には上述の 問題が無視できるので, SPP 法は用いずスループット法で 測定する. スループット法による測定時は，バルブ $\mathrm{V}_{\mathrm{U}}$ 開, $\mathrm{V}_{\mathrm{D}}$ 閉にし, $\mathrm{B}-\mathrm{A}$ 真空計 1 の圧力と B-A 真空計 2 の圧力差 にオリフィスコンダクタンス $C$ をかけて気体流量を求め る. その後ベーキングを行い, ベーキング後の気体放出速度 を求める際に SPP 法を用いる. Fig. 6 に測定中の圧力変化 の一例を示した. 流路を切り替えると, B-A 真空計 1 の值 は変化するが，B-A 真空計 2 の圧力は変化しない。

SPP 法では, 流路を切り替えると圧力が一定值に落ち着 くまでに数時間程度の時間が必要である. そのため SPP 法 では連続的な測定はできず，時間的に気体放出速度が变化す る場合の測定には向かない。

また本装置は, ベーキングの後, 温度を段階的に変化させ

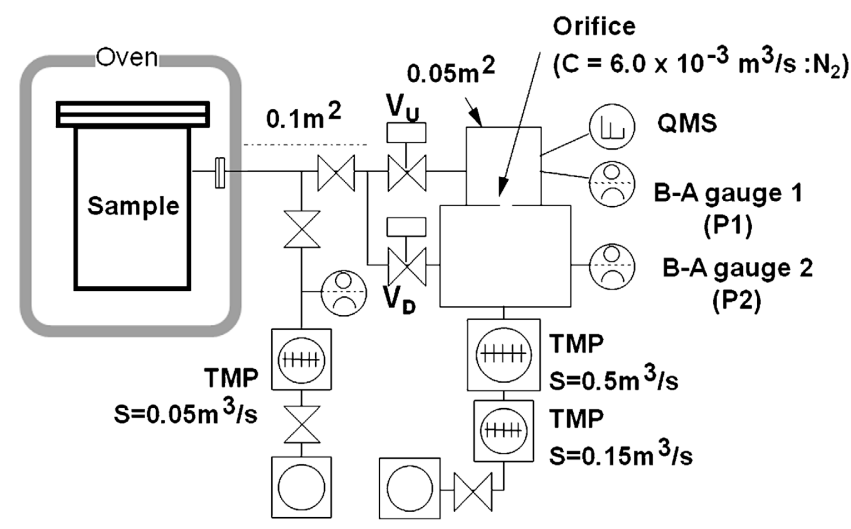

Fig. 5 Schematic diagram of the apparatus used for the SPP method. 


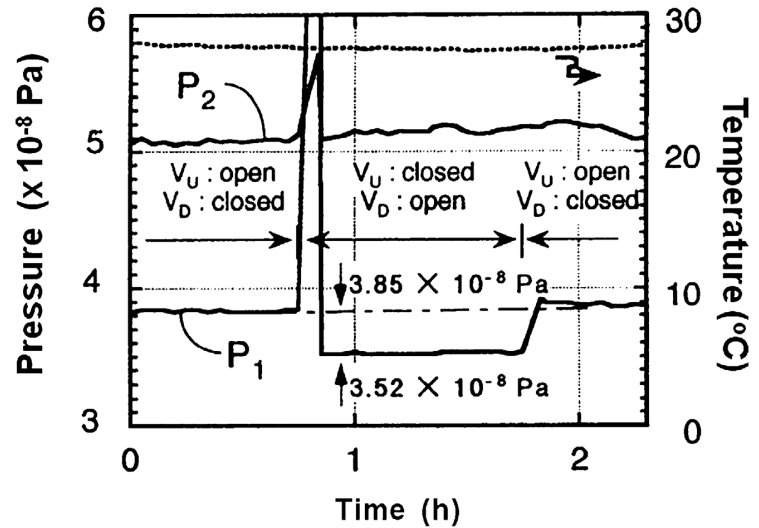

Fig. 6 Upstream pressure $\left(P_{1}\right)$ and downstream pressure $\left(P_{2}\right)$ at the orifice in the SPP apparatus.

ながらそれぞれの温度で SPP 法による気体放出速度測定が できる．測定結果をアレニウスプロットし，ベーキング後の 脱離の活性化エネルギーを求めることができる ${ }^{24)}$.

\subsection{SPP 法測定結果例}

ステンレス鋼製真空容器をSPP 法により測定した例を示 す32)。試料は，UFC253 フランジが両端についた円筒状の ステンレス鋼製真空容器 (内表面積 $: 0.28 \mathrm{~m}^{2}$ ) であり, 全 面が化学研磨・精密洗浄処理されている（以下では試料 CP と呼ぶ)。試料 $\mathrm{CP}$ を装置に取り付け大気圧から排気し， 150 ${ }^{\circ} \mathrm{C} \times 20 \mathrm{~h}$ のベーキング後に温度を $28^{\circ} \mathrm{C} \rightarrow 40^{\circ} \mathrm{C} \rightarrow 50^{\circ} \mathrm{C} \rightarrow 60^{\circ} \mathrm{C}$ $\rightarrow 70^{\circ} \mathrm{C} \rightarrow 80^{\circ} \mathrm{C} \rightarrow 90^{\circ} \mathrm{C} \rightarrow 100^{\circ} \mathrm{C} \rightarrow 80^{\circ} \mathrm{C} \rightarrow 60^{\circ} \mathrm{C} \rightarrow 40^{\circ} \mathrm{C} \rightarrow 28^{\circ} \mathrm{C}$ と段 階的に変化させながら SPP 法で気体放出速度を測定した。 $28^{\circ} \mathrm{C}$ に打ける気体放出速度は $2 \times 10^{-9} \mathrm{Pams}^{-1}$ であった。

Fig. 7 に気体放出速度のアレニウスプロットを示す.デー タ点はほぼ直線上に並んで抢り,このときの脱離の活性化工 ネルギー $\mathrm{E}_{\mathrm{d}}$ が $53 \mathrm{~kJ} / \mathrm{mol}$ であることが計算できる.

また，SPP法を四重極質量分析計のマススペクトルに適 用した $28^{\circ} \mathrm{C}$ での結果を Fig. 8 に示す。 $\mathrm{V}_{\mathrm{U}}$ 開 $\mathrm{V}_{\mathrm{D}}$ 閉のときの Ion current $\mathrm{U}$ も， $\mathrm{V}_{\mathrm{U}}$ 閉， $\mathrm{V}_{\mathrm{D}}$ 開のときの Ion current $\mathrm{D}$ の マススペクトルも主に検出された $m / z$ は， $2,18,28,44$ であ った. Ion current U と Ion current D の差をとり, 試料か らの気体放出のマススペクトルを得ると, $m / z=2$ の水素だ けであることがわかった。すなわち試料 $\mathrm{CP}$ の場合， $150^{\circ} \mathrm{C}$ $\times 20 \mathrm{~h}$ のベーキング後, $28^{\circ} \mathrm{C}$ での $Q_{\mathrm{s}}$ の主な気体種は水素 であることまた， $m / z=18,28,44$ は試料以外の $Q_{\mathrm{U}}$ や $Q_{\mathrm{D}}$ に 起因することがわかった。

この測定では, 室温における $P_{1 \mathrm{u}}$ と $P_{1 \mathrm{~d}}$ の圧力差 $\Delta P_{1}$ は約 $9 \times 10^{-8} \mathrm{~Pa}$ である. Fig. 5 の測定装置の到達圧力は $10^{-8} \mathrm{~Pa}$ 台であるため, $10^{-11} \mathrm{Pam}^{3} \mathrm{~s}^{-1} \mathrm{~m}^{-2}$ より小さい気体放出速 度を求めるには, 試料表面積を大きくしたり, より低い圧力 まで排気できるポンプを用意したりする必要がある，真空計 も適宜より低い圧力が測定できるものに変える必要があ $\succsim^{33)}$.

コンダクタンス変調法, SPP 法は測定の手法を工夫した ものであるが，最近の報告では，気体放出を極力抑制した四 重極質量分析計を使って新たな気体放出測定を行う提案もな されている34).

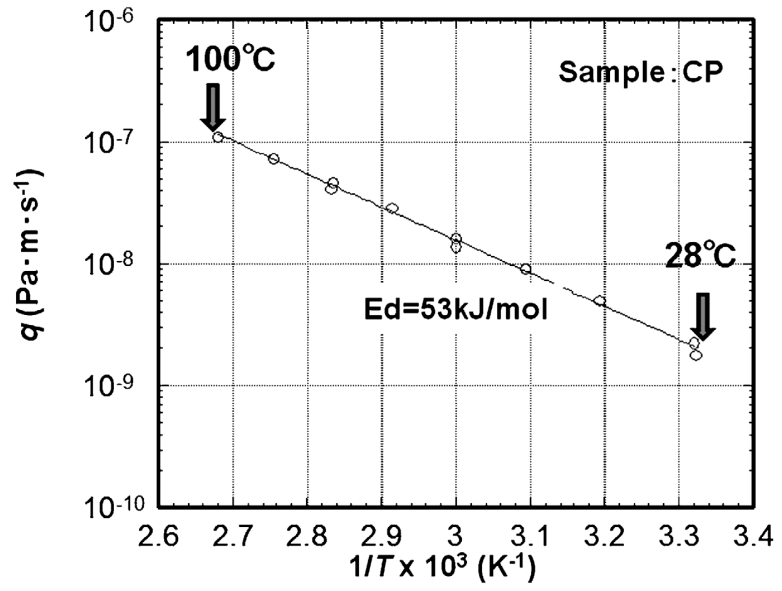

Fig. 7 Temperature dependence of the outgassing rate $q$ in the SPP apparatus.

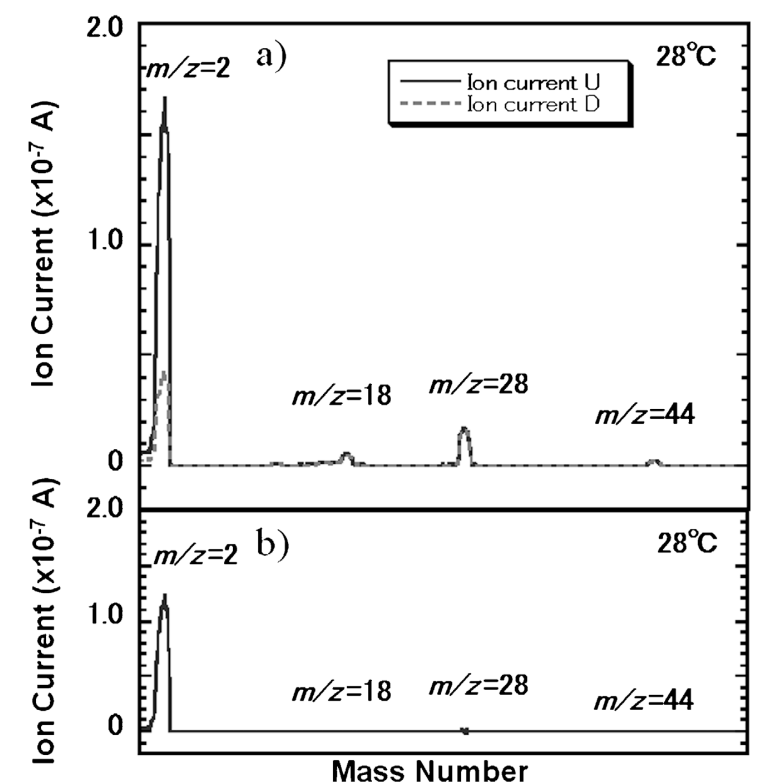

Fig. 8 a) Mass spectra measured at $28^{\circ} \mathrm{C}$ at the upstream side and downstream side.

Ion current $\mathrm{U}$ : $\mathrm{V}_{\mathrm{U}}$, open; $\mathrm{V}_{\mathrm{D}}$, closed. Ion current $\mathrm{D}$ : $\mathrm{V}_{\mathrm{U}}$, closed; $\mathrm{V}_{\mathrm{D}}$, open.

b) Difference of ion current $\mathrm{U}$ and ion current $\mathrm{D}$.

\section{5. まとめ}

真空材料の熱脱離による気体放出速度測定について我々の 製作した昇温脱離法測定装置, 流路切り替え法測定装置を中 心に概観した。真空装置で使う材料の実用的な気体放出特性 評価の一助となれば幸いである。

\section{〔文献〕}

1) Y. Ishikawa, K. Odaka, S. Ueda and H. Kamohara: Shinku, 32 (1989) 444.

2) M. Miyamoto, T. Itoh, S. Kobari, K. Narushima and H. Ishimaru: Shinku, 28 (1985) 87.

3) S. S. Inayoshi, K. Saito, Y. Ikeda, Y. Yan and S. Tsukahara: Shinku, 36 (1993) 238.

4) Y. Ishikawa: Shinku, 49 (2006) 335. 
5) M. Hashiba, K. Akimoto, T. Hino and T. Yamashina: Shinku, 34 (1991) 95.

6) Y. Nobuta, Y. Yamaguchi, T. Hino and H. Yoon: J. Vac. Soc. Jpn., 55 (2012) 164.

7) K. Saito, S. Inayoshi, Y. Ikeda, Y. Yang and S. Tsukahara: J. Vac. Sci. Technol. A, 13 (1995) 556.

8) D. Fujita: Shinku, 45 (2002) 402.

9) S. S. Inayoshi and F. Ishigure: Shinku, 50 (2007) 205.

10) A. Itakura, M. Tosa and K. Yoshihara: Shinku, 37 (1994) 240.

11) M. Minato and Y. Itoh: J. Vac. Sci. Technol. A, 13 (1995) 540.

12) H. Kurisu, S. Yamamoto, M. Matsuura, T. Motimoto and M. Hesaka: Shinku., 50 (2007) 41.

13) F. Watanabe: Shinku., 49 (2006) 349.

14) M. Fukaya, S. Teraoka, Y. Sato, M. Uota and Y. Saito: Shinku., 49 (2006) 357.

15) M. Kinsho, Y. Saito, Z. Kabeya and N. Ogihara: Shinku., 49 (2006) 728.

16) T. Kubo, Y. Sato and Y. Saito: Shinku, 41 (1998) 217.

17) Y. Sato, S. Takada, T. Omori, N. Kimuta, T. Suzuki and Y. Saito: J. Vac. Soc. Jpn., 56 (2013) 422.

18) Y. Sato, T. Kubo, I. Sakai and Y. Saito: Shinku, 43 (2000) 962.

19) P. A. Redhead: Vacuum, 12 (1962) 203.

20) G. Carter: Vacuum, 12 (1962) 245.

21) Y. Hirohata: Shinku, 33 (1990) 488.

22) Y. Ishikawa: Shinku, 43 (2000) 214.
23) K. Terada, T. Okano and Y. Tuzi: J. Vac. Sci. Technol. A, 7 (1989) 2397.

24) K. Saito, Y. Sato, S. Inayoshi, Y. Yang and S. Tsukahara: Shinku, 38 (1995) 449.

25) S. Komiya, Y. Sugiyama, M. Kobayashi and Y. Tuzi: J. Vac. Sci. Technol., 16 (1979) 689.

26) S. Inayoshi, K. Saito and M. Matsuura: ULVAC TECHNICAL JOURNAL, No. 58 (2003) 30.

27) C. M. Chan and W. H. Weinberg: Appl. Surf. Sci., 1 (1978) 377.

28) M. Takeda, H. Kurisu, T. Uchida, S. Yamamoto, K. Ishizawa, T. Nomura, T. Eda and N. Murashige: J. Vac. Soc. Jpn., 53 (2010) 136.

29) S. S. Inayoshi: Shinku, 50 (2007) 228.

30) H. Yoshida, K. Arai, M. Hirata and H. Akimichi: Vacuum, 86 (2011) 838.

31) S. Inayoshi, K. Motegi, H. Yoshida, H. Akimichi and T. Ohada: $50^{\text {th }}$ Annual Symposium of the Vacuum Society of Japan kouen yoko syu (Tokyo, 2011) p. 125.

32) S. Inayoshi, K. Saito, Y. Sato, S. Tsukaraha, Y. Hara, S. Amano, K. Ishizawa, T. Nomura, A. Shimada and M. Kanazawa: Shinku, 41 (1998) 96.

33) S. Ichimura, M. Kokubun, M. Hirata, S. Tsukahara, K. Saito and Y. Ikeda: Vacuum, 53 (1999) 291.

34) F. Watanabe: J. Vac. Soc. Jpn., 51 (2008) 647. 